\title{
Review
}

\section{A Review of Values of Green Building at Building and City Scales}

\author{
Le Thi Kieu* ${ }^{\circledR}$, Stefan Schäfer ${ }^{(1)}$ \\ Institute of Constructive Design and Building Construction, Technical University of Darmstadt, 64287 Darmstadt, Germany \\ E-mail: kieu@kgbauko.tu-darmstadt.de
}

Received: 30 September 2019; Revised: 2 November 2020; Accepted: 10 November 2020

\begin{abstract}
Green Building is the term used for the buildings characterized by a higher energy and water efficiency, a lower use of natural resources and materials compared to the conventional buildings and an improvement in the health and comfort of the living environment. Since this building concept primarily focuses more on the ecological and the social factors, within the three aspects of a sustainable development, the economic benefits of Green Building are less discussed despite their presence. Therefore, this paper aims to look for the various values of Green Buildings at building and city levels through a summary of relevant secondary data. At the building level, in comparison with the conventional buildings, the values of Green Building are obtained from a saving of operation cost, a larger return compared to the initial cost, a shorter payback period, a higher property value, a higher transaction, rental and occupancy rate as well as an improvement in the occupants' health and productivity. At the city level, their values reflect through a lower demand for the urban technical infrastructure capacity, market expansion, job creation and higher tax collection possibilities. Since these values are gained through various ways, this paper indicates the positive relations between environmental and economic benefits at both building and city scale. By these findings, it contributes to the emerging literature on the benefits of Green Building that helps to promote further the development of Green Building in the future.
\end{abstract}

Keywords: Green Building, values, green cities, sustainable development

\section{Introduction}

As reported by the International Energy Agency and United Nation Environment, 36\% of the final energy consumption and $39 \%$ of $\mathrm{CO}_{2}$ emissions in 2017 were caused by the activities related to building construction and operation [1]. Due to the growth of population rate worldwide, it is estimated that the demand for construction keeps rising in the future that results in even higher needs of energy and a higher amount of emitted pollutants. Therefore, it is crucial to seek for sustainable solutions which help the building industry less rely on non-renewable energy resources as well as reduce its negative impacts on the environment.

Among these solutions, Green Building construction has been promoted and developed in many countries. According to the World Green Building Council (WorldGBC) [2], Green Building is an interdisciplinary term used for the buildings whose design, construction and/or operation helps lower the negative while increasing the positive impacts on the climate and natural environment, and therefore "preserves precious natural resources and improves the quality of life." Besides Green Building, some other terms are interchangeably used for buildings with these features such as "High Performance Building" [3], "Sustainable Building" [3-5] and "Sustainable Architecture" [3, 6, 7]. Based on these

Copyright (C2020 Le Thi Kieu, et al.

DOI: https://doi.org/10.37256/gbce. 112020620

This is an open-access article distributed under a CC BY license

(Creative Commons Attribution 4.0 International License)

https://creativecommons.org/licenses/by/4.0/ 
concepts of Green Building which primarily focus on the ecological and social aspects of Green Building respectively, the ecological and social benefits are obviously discussed more often than the economic benefits. In other words, the values of Green Building are less mentioned despite their presence.

However, in several cases the cost and benefit balance are among the top important criteria in a development project. In other words, most of projects are only implementable if a sufficient economic return on the investments is foreseeable. Being aware of the values of Green Building can greatly support the stakeholders including building owners, construction consultants and policy makers in their decision-making processes. Therefore, this paper aims to carry out a secondary study to synthesize the values of Green Building at the building level and explores certain values possibly gained at the city level.

\section{Methodology}

This paper mainly uses secondary data documented in reports and scientific papers as well as certain relevant information from websites concerning various topics and issues in Green Buildings. Firstly, reports are referred from the organizers that have their research activities associated with sustainable construction in general, such as the works of the United Nations on the global status of building industry and Green Building development in particular, the reports by the WorldGBC-the largest organization concerning Green Building worldwide-working on the global development of Green Building. The data found in their reports cover the most significant issues with a relatively high reliability level. Besides, these data are updated regularly with supporting information from their members and partners that helps the readers to have a comprehensive overview of a certain topic throughout the time. Secondly, with an aim to keep this paper updated with the latest data, most of the referred scientific papers are the materials published in the journals indexed by SCOPUS within the last decade (2010-2020). Finally, when relevant, data are also collected from the websites that discuss the latest news that has not been mentioned in any reports and scientific works so far.

Data from the aforementioned sources are first filtered according to their relevance to the main topic, categorized under either building or city scale regarding their scope of economic values and finally grouped as sub-topics. Under these sub-topics, data from different sources are summarized and synthesized when relevant to draw a comprehensive overview. In order to compare between projects as well as to have a wider view on the range, some numerical data are also further processed to obtain the same indicators and units. An example of this process might be found in Table 1. To illustrate the trend throughout time, certain data are graphed with the Origin software whose results are shown at Figure 1 and Figure 2.

\section{Results}

An overview on literature about values of Green Buildings indicates a gap in data availability between building and city scale. The used metrics found in the existing literature body already reflect a developed recognition of these values at building scale, particularly at the certified projects; however, they are not yet sufficiently gathered in a single document. On the contradictory, values at the wider scales are less documented and mentioned incoherently in a few secondary materials. Therefore, these values are gathered and analyzed below as a contribution to the emerging body of literature on this topic.

In cost and benefit balance, an outcome with a higher value can be achieved by:

(1) A reduction of cost with the same benefits,

(2) An increase in benefits with the same cost,

(3) An increase in benefits that exceeds the increase in cost, and

(4) Both of a cost reduction and a benefit increase achieved.

Therefore, the values of Green Building discussed below follow these strategies. Following the research questions, the authors summarize values of Green Building at the building level (4.1) and the city level (4.2) in Chapter 4. At each level, values gained from different strategies are highlighted as the sub-title at the beginning of the content. 


\subsection{Values of Green Building at building scales}

There are several metrics used to measure business benefits of Green Building. The majority of values listed below are generally based on the popularity of the tracking methods recognized in a report of McGraw-Hill Construction which belongs to a report series providing important summaries and insights on the development trend of Green Building worldwide [8].

\subsubsection{Values from operating cost saving}

Globally, reduction in operation cost is considered as the most important benefit of Green Building [9]. Due to its measurability, this benefit is also one of the most documented and quantified so far [9]. Its direct values can be predicted from water and energy consumption in different manners depending on the usage structure. For non-rental buildings, the owners, also as the users, are the benefit holders of these savings. For rental buildings, depending on the contract between owners and tenants, the values of Green Building obtained from a smaller utility bill can benefit the owners in gross lease or the tenants in net rent.

A study on financial performances figured out that it costs $\$ 675.26$ less for the annual utility per employee in green than in non-green facilities [10]. From 2012-2019, it is estimated that 770,000 retrofitted and Green Building certified units in the Multifamily Green Bond program (U.S.) have saved \$126 million in cumulation for utility. On average, each of the projected households spent $\$ 178$ less per year thanks to energy and water efficiency [11]. There is a positive development in these figures that only within 2019, they saved \$254 that already way exceeds the average annual saving during 2012-2018, which was only \$145 [12].

Saving from the utilities during the buildings' operation offers a high financial efficiency for the green investors. For the building units in the Multifamily Green Bond program, it is estimated that after only 22-26 months the investments to energy and water efficiency will be returned, regardless of their construction years [12]. Additionally, in a report sent to the California's Sustainable Building Task Force, Kats et al. summarized costs and benefits of 33 Green Buildings and discovered that energy savings alone exceed the average extra cost paid for Green Buildings after 20 years of operation [3].

Not only benefiting with lower utility bills, energy saving at the certified energy efficient office buildings also has a direct correlation to their value, according to Eichholtz et al. [13]. Specifically, a decrease of $10 \%$ in energy consumption results in an increase of $1.1-1.2 \%$ in building value and rental premium [13].

\subsubsection{Small costs return big values}

In the same report of Kats et al., an extra premium cost, ranging from $0.66 \%$ for LEED-certified buildings to $6.50 \%$ for LEED-Platinum certified buildings, was spent to incorporate Green Building features into the case studies. On average, this extra cost exceeds the basic construction cost with an amount of only $1.84 \%$ but returns a minimum value of 10 times higher after 20 years [3].

\subsubsection{Cost of Green Building can be optimized}

In the same report mentioned above, Kats et al. also figured out that building cost increases mainly due to a longer time taken to incorporate Green Building elements in architectural and engineering design process while cost saving is achieved by the lower utility bills and maintenance costs [3]. Therefore, the value of Green Building can be optimized by an early involvement of these sustainable elements into the decision-making process. In fact, a lean integrated project delivery (Lean-IPD) applied in the design process of the Akron Children's Hospital, U.S., resulted in a project completion of 54 days ahead of schedule and saved $\$ 44$ million for its construction cost [14]. It is also commonly found in the U.S. and some other places the benefits for Green Building developers that include tax grants and credits, fee waivers and priorities to access certain loan funds (so-called the financial incentives) as well as a shorter time waiting for building permits, density and height bonus (e.g. 10\% of Gross Floor Area bonus given to participants of the Hong Kong's Concession Scheme to promote Green Building development [15]), technical and marketing assistances (so-called the non-financial incentives) $[16,17]$.

Among the perception of Green Building, there is a common belief that it initially costs more than conventional 
buildings [18] that it becomes the top barrier in promoting Green Building activities [9]. However, this hypothesis is remaining untested due to one of the facts that data on building cost is not widely accessible. While the cost is still uncertain in several cases, Green Buildings at certain places actually used green materials with no added cost or even less cost than the conventional buildings thanks to negotiations [3]. As building codes around the world have become stricter, the demand for Green Building development is getting higher that attracts the involvement of more green suppliers in Green Building markets. With this recent rapid development in manufacturing and market, it is promising that green materials will be more affordable that motivates more developers for Green Building construction.

Although higher initial cost is still the top barrier for Green Building development so far, the studies by Dogde Data \& Analytics in 2012, 2015 and 2018 indicate a dramatical decrease in this concern, from 76\% (2012) to 50\% (2015) and 49\% (2018) of the respondents in a series of surveys implemented by the WorldGBC [9, 19] (The surveys were implemented mainly with the Green Building Councils in many countries worldwide as they are members of the WorldGBC and with the WorldGBC's partners in statistical analysis. Respondents of these surveys are architects/design firms, contractors/builders, specialists/consultants, owners/developers, engineering firms and investors. Respondents are from and at 62-86 countries worldwide, and data analysis were statistically conducted for notable results from 9 countries in 2012, 13 countries 2015 and 19 countries in 2018 [8, 9, 19]). One factor that might influence this change is the drop of this cost in the total construction cost through time possibly thanks to the presence of more affordable green materials on the market as well as more experiences of the developers in Green Building construction and renovation and so on.

\subsubsection{Shorter payback periods for green investments}

A reduction in payback period is expected for both new and retrofitted buildings through time. Globally, green investments will be paid back after 7 years for new green buildings and after 6 years for green retrofitted buildings in 2018 [9]. These numbers indicate a positive development in Green Building that they were both 1 year greater for a similar survey implemented in 2012 [8].

Specifically, Figure 1 indicates payback periods through time from 2012-2018 for new Green Building after giving questions to $74 \%$ of respondents of the same surveys by the WorldGBC and Dogde Data \& Analytics who recognized that Green Buildings cost more than conventional buildings [9]. According to them, six to ten years seem to be the most common payback time that was found in $41-44 \%$ cases, while from time to time, there are increasing cases reported with a shorter payback time (under 5 years) and decreasing cases reported with a longer pack time (above 10 years).

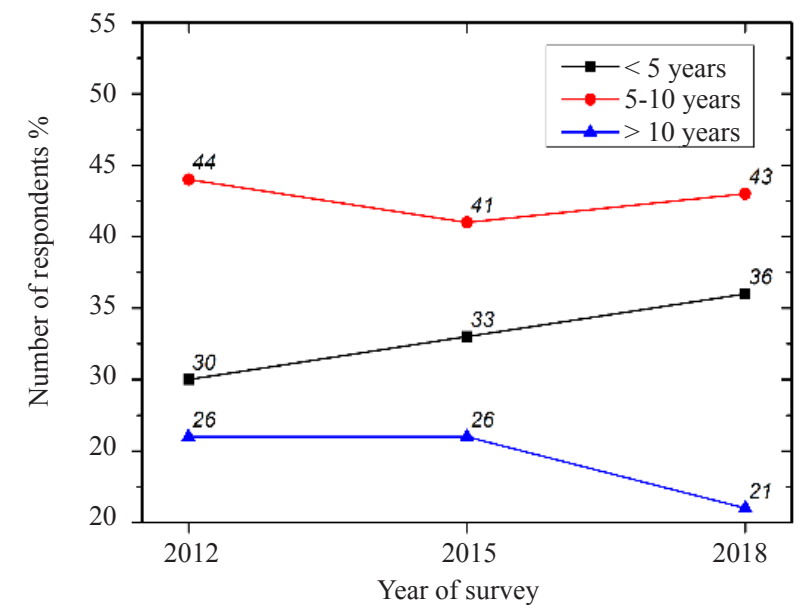

Figure 1. Payback period for extra cost to construct a new Green Building in 2012-2018. The percentages given represent for the respondents of the surveys, who had their entire payback return in the given period of time. (Adapted from [9], cf. Pg. 36) 


\subsubsection{Higher property value and higher transaction, rental and occupancy rates}

According to the WorldGBC, new and renovated buildings with Green Building features respectively have their values from $5 \%$ to $7 \%$ and from $4 \%$ to $7 \%$ higher than the conventional buildings [9]. Specifically, in 2012,2015 and 2018, the WorldGBC carried out surveys asking the owners, architects and contractors for their estimations of the asset values of the new Green Buildings. There were $96 \%$ of owners and $70-72 \%$ of architects and contractors reporting or estimating that these buildings have higher asset values than the conventional ones [9]. Interestingly, there are more and more respondents from both groups believing that the green features contribute at least $10 \%$ exceeding values to these properties. This growth in number is seen from Figure 2, from 16\% of building owners and 18\% of architects and contractors in 2012 , to $30 \%$ of the first group and $27 \%$ of the second group in 2018 . At the same time, there was also a drop in percentage of respondents in both groups, from 53\% and 61\% in 2012 to $46 \%$ and 53\% in 2018 respectively, who believed the new Green Buildings obtain only up to $5 \%$ increase in value.

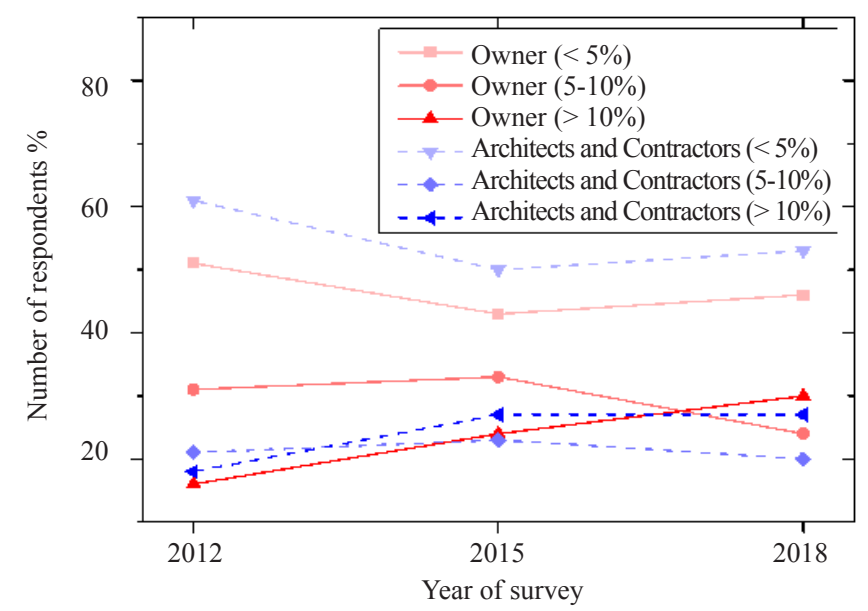

Figure 2. Estimations of building owners, architects and contractors for the increase in asset values of new Green Buildings in comparison with the traditional buildings (2012-2018) (Adapted from [9], cf. Pg. 37)

Besides an increase in asset value, Green Buildings also have a higher rent values compared to the traditional properties that some of them are summarized in the Table 1 . These values vary according to the market as well as the level of green certificates that the buildings get awarded.

Table 1. A summary of the increase in asset and rent values of Green Buildings (2010-2020)

\begin{tabular}{|c|c|c|c|c|c|}
\hline Increase in asset value & Increase in rent value & Building types & Country or Region & Source of reference & Year of report \\
\hline $43 \%$ & $23 \%$ & Office & Germany & {$[20]$} & 2018 \\
\hline $7.4-11 \%$ & - & Office & Italy & [21] & 2018 \\
\hline $\begin{array}{c}2.6-4.1 \% \\
\text { (in average: } 3.2 \% \text { ) }\end{array}$ & - & Residential & Singapore & [22] & 2018 \\
\hline $2 \%$ & - & Commercial & Singapore & [23] & 2018 \\
\hline $4.4 \%$ & - & Residential & Hong Kong & [24] & 2017 \\
\hline $6.9 \%$ & - & Residential & China & [25] & 2016 \\
\hline- & $3-4 \%$ & Office & U.S. & {$[26,27]$} & 2015,2017 \\
\hline- & $5-8 \%$ & Office & U.S. & {$[27]$} & 2017 \\
\hline $11.8 \%$ & $6.6 \%$ & Office & Australia & [28] & 2014 \\
\hline
\end{tabular}


High performance buildings expectedly affect the decisions of buyers in purchasing properties and tenants in leasing spaces [16] that finally leads to a higher transaction rate in a shorter time than the conventional buildings. Plantronics Office is a good example of this positive impact when the tenant was so pleased with the building quality that they asked to purchase the building immediately after the construction and benefited the developer about $\$ 624,000[14]$.

Moreover, occupancy is found higher for rated Green Buildings compared to those of non-rated buildings [29]. According to a study by Mangialardo et al. (2018), within half of a year after construction, vacancy rates of certified Green Buildings in Milan, Italy were only 20\% while those of conventional buildings were reported at 79\% [21]. In the U.S., Green Buildings typically have 4\% (LEED) and 9.5\% (ENERGY STAR) higher occupancy rates [26].

\subsubsection{Improvement of occupant health and labor productivity}

Improving occupant health and productivity are among the top social reasons for building green in Europe, besides the encouragement for sustainable business practices [9]. Moreover, it is being said that entrepreneurs typically spend up to $90 \%$ for staff associated cost [30]; therefore, if such improvement can help save cost expensed for staff, the business runners will be benefit largely at the end. Thus, it is another motivation for Green Building developers besides the labelling-related benefits from the recognition of a business with environmental commitments and social responsibilities.

Saving from these factors mostly remain unpredicted compared to the benefits associated with resources and values. However, there are some reports providing valuable overviews resulting from some surveys on these factors. Based on a survey with 5,220 firms, Delmas et al. found a higher labor productivity in the green firms who have commitments to develop towards a sustainable environment [31]. Specifically for green offices, reports published by the WorldGBC have reviewed several economic benefits offered by the business runners due to the increase in health and wellbeing of their employees [14, 30]. Certain selected benefits are summarized in Table 2.

Table 2. A summary of business benefits from an improvement of occupant heath and productivity in green office buildings. Data is selected from case studies in $[14,30]$ and listed following a descending in number of staff

\begin{tabular}{|c|c|c|c|c|c|c|}
\hline Projects & Area $\left(\mathrm{m}^{2}\right)$ & $\begin{array}{l}\text { Number of } \\
\text { Staff }\end{array}$ & Annual outcomes & Annual savings & $\begin{array}{l}\text { Annual savings } \\
\text { per } \mathrm{m}^{2}\end{array}$ & $\begin{array}{l}\text { Annual savings } \\
\text { per employee }\end{array}$ \\
\hline $\begin{array}{l}\text { Vondellaan } 47 \text { (The } \\
\text { Netherlands) [30] }\end{array}$ & 23,336 & 1,100 & $\begin{array}{l}\text { (unknown percentage) increase } \\
\text { in productivity, staff retention } \\
\text { and decrease in sick leaves }\end{array}$ & $\begin{array}{l}\text { Min. } \$ 2.5 \\
\text { million }\left(^{*}\right)\end{array}$ & $\$ 107$ & $\$ 2,273$ \\
\hline Cundall Office (U.K.) [14] & 1,500 & $170+$ & $\begin{array}{c}27 \% \text { decrease in staff turnover } \\
\text { and } 4 \text { days decrease in sick } \\
\text { leaves }\end{array}$ & $\begin{array}{l}\$ 252,000 \\
(* *)\end{array}$ & $\$ 168$ & $\$ 1,482$ \\
\hline $\begin{array}{l}\text { Sherwin-Williams Office } \\
\text { (refurbished) } \\
\text { (El Salvador) [14] }\end{array}$ & 1,710 & 150 & $44 \%$ decrease in sick leaves & $\$ 85,000$ & $\$ 50$ & $\$ 567$ \\
\hline $\begin{array}{l}\text { Plantronics Office (The } \\
\text { Netherlands) [14] }\end{array}$ & 3,531 & 135 & $\begin{array}{l}11.7 \% \text { increase in employee's } \\
\text { productivity }\end{array}$ & 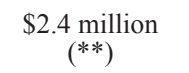 & $\$ 680$ & $\$ 17,778$ \\
\hline Skanska Office (U.K.) [30] & 1,800 & 110 & 3.5 days decrease in sick leaves & $\$ 36,000$ & $\$ 20$ & $\$ 327$ \\
\hline Stok Office (U.S.) [14] & 2,323 & 70 & $25 \%$ decrease in sick leaves & App. $\$ 4,500$ & $\$ 2$ & $\$ 64$ \\
\hline
\end{tabular}

Notes for Table 2:

(*) €42 million net present value in 20 years equally

$(* *) € 2.1$ million equally

$(* * *) £ 200,000$ equally

According to Table 2, savings gained from the improvement of occupant health and labor productivity are ranging from $\$ 2$ to $\$ 680$ per $\mathrm{m}^{2}$ and from $\$ 64$ to $\$ 17,778$ per employee. It depends largely on the business demands to define their working space and/or employee number as well as expense rates; however, there is a common trend to see from the data that the more employee a company has, the higher value per employee it likely gains from the investments in Green 
Building features. In other words, it is typically worthier to invest in bigger scaled projects where impacts of Green Building can benefit a larger number of users. However, a similar connection is not found between the project area and its unit investment.

\subsection{Values of Green Building at city scales}

As mentioned in the Introduction, values of Green Building so far have been more discussed at building level rather than on a wider level. However, besides the direct values that cities have from implementing their construction projects with Green Building standard, there are certain benefits that are scaled up from building level as well as scaled down from national- to city-level. These benefits are discussed in the following chapters.

\subsubsection{Smaller investments in upgrading urban technical infrastructure}

According to the United Nations [32], urban population rate is estimated to increase from $67 \%$ (2018) to $83 \%$ (2050). The rural-to-urban migration on one hand benefits the cities with a considerable contribution to their labor force; however, on the other hand, it puts a higher pressure on the existing structure of the cities in multiple aspects. To respond with a higher demand from the increasing population, upgrading their infrastructure system to reach a higher capacity is one of the common objectives found in urban development and planning scheme. However, these upgrading programs often require a costly investment.

By the development of Green Building, this pressure can be eased. In a study by Bouton et al. [33], it is summarized that Green Building consumes $20-40 \%$ less energy, $60-65 \%$ less freshwater and therefore produces less wastewater and discharges $25 \%$ less solid waste in comparison to the conventional buildings. In other words, within urban technical infrastructure, energy generating and distributing system, water supply system and waste treatment system are directly benefited from Green Building (Figure 3).
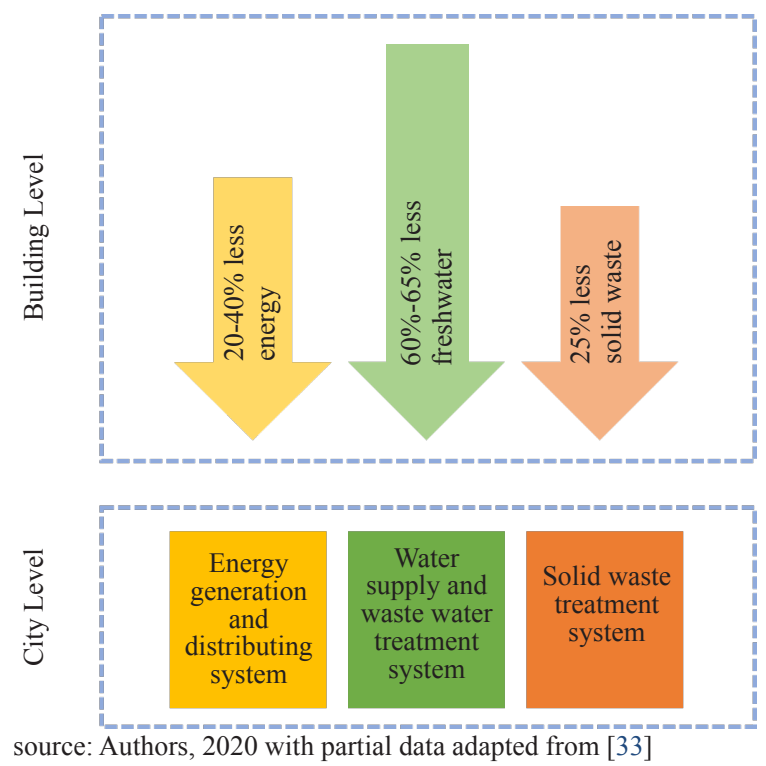

Figure 3. Relationships between benefits of Green Building at building level and technical infrastructure at city level

Particularly, during certain unusual weather events such as heavy or extreme rainfall, a large amount of rainwater may create a high pressure on the wastewater discharging and treating system. Instead of investing to enlarge the capacity of such system that can be both time and cost consuming, Green Building strategies such as rainwater catchment and Green Roof may help reduce the amount of wastewater catching at once for urban infrastructure. Specifically, a study by HMFH Architects and Vermont Energy Investment Corp estimated that the city Dedham, 
Massachusetts, U.S. may save \$400,000 from infrastructure improvement thanks to such strategies [34]. Similarly, potential values from city-wide Green Roof are estimated to save the city of Toronto, Canada, $\$ 118$ million initial cost for the development of their storm water treatment system and $\$ 46$ million initial cost for the development and $\$ 750,000$ yearly cost for the operation and maintenance of their Combined Sewer Overflow (CSO) system, summarized by [35]. Realizing these values, since 2009, Toronto became the first city of North America to regulate by law the construction of Green Roof for the newly built or additional roofs that exceed 2,000 $\mathrm{m}^{2}$ in gross floor area [36].

Besides values related to wastewater discharge and treatment, the positive ecological impacts from Green Roof also helps to improve air quality and save utility fees for the governmental offices. The benefits for public health gained from less air pollution were estimated at \$890-3,390 annually per 2,000 $\mathrm{m}^{2}$ of Green Roof in general [37]. In Chicago, U.S., with $1,886 \mathrm{~m}^{2}$ (20,300 square feet) of Green Roof on the City Hall (Figure 4), the city expects to pay $\$ 3,600-5,000$ less for building energy. In other words, about \$1.90-2.65 can be saved for energy consumption per square meter of Green Roof [35].

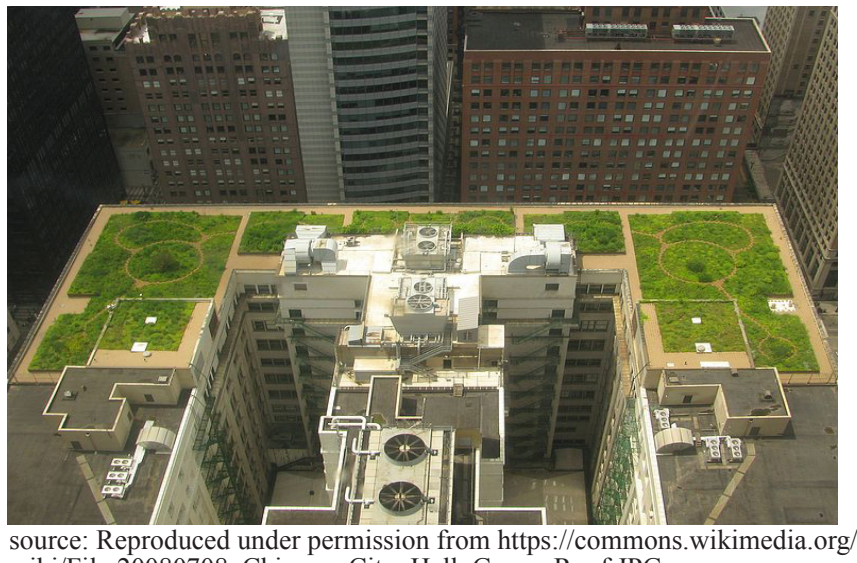
wiki/File:20080708_Chicago_City_Hall_Green_Roof.JPG

Figure 4. Green Roof on Chicago city hall

Since Chicago is topped for their total area of Green Roof among the U.S. with 5.6 million square feet or 517,000 square meters of green roof coverage as of 2013 [38], the city themselves can save about $\$ 0.98-1.36$ million on the city scale (Figure 5). For other cities, this method can be used to estimate the potential values of Green Roof based on the value in area unit and their actual Green Roof areas.

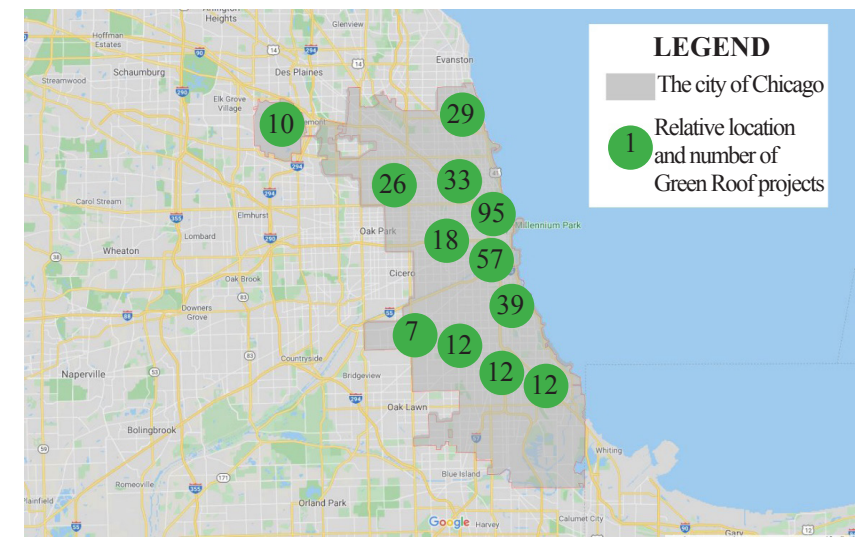

source: Authors, 2020, adapted from Google Maps and open-accessed geographical data found at https://data.cityofchicago.org/Environment-Sustainable-Development/Green-Roofs-Map/u23m-pa73

Figure 5. Relative locations and number of Green Roof projects in the city of Chicago, U.S. 


\subsubsection{Short payback periods for investments to green districts}

In the same study by Bouton et al., green investment per capita in Green Districts costs $\$ 1,000$ to $\$ 4,000$ and results in an annual saving of $\$ 250$ to $\$ 1,200$ for each resident. Along with the operation of the districts, it is estimated that the initial costs are likely to be returned after 3 to 5 years, depending on the projects' features and invested technologies [33]. This payback period of Green Districts is relatively shorter than of Green Buildings because more than $60 \%$ of Green Building investors must wait for at least 6 years to be benefited from their projects, as mentioned in Figure 1. This benefit once more time implies that green investment on a wider scaled project with more users brings more values to the developers.

\subsubsection{Expansion of energy efficiency market}

According to reports from Dodge Data \& Analytics and McGraw-Hill Construction in 2008, 2012, 2015 and 2018, the top triggers motivating Green Building development are high client demands (2008-2018), following by environmental regulations (2015-2018) and market demands (2008-2012).

The willingness of the investors to pay more and the stricter environmental regulations in many countries result in a higher number of manufacturers and suppliers whose activities concern Green Building products. At the same time, Green Building markets also become more bustling. This consequence also result from the desires of Green Building developers that more than half of them would like to supports their domestic economy via the activities related to Green Building development [9]. Particularly in the U.S., 97\% of these economic activities are expected to occur within the country [6] which obviously promotes the local economy at city scale.

In the same survey implemented by the WorldGBC and their partners, $47 \%$ of respondents globally expect to have more than $60 \%$ of their projects sustainable in 2021 . This percentage increases tremendously from $27 \%$ of respondents in 2018 [9]. This higher commitment from developers is promising for the Green Building market worldwide. Despite Covid-19 pandemic that has been affected all markets worldwide, this market is still expected to grow $8.6 \%$ annually from 2020 to 2027. Over this period, Germany alone might add \$6.8 billion to upsize the European Green Building market [39].

The Green Building markets recently get quickly expanded also in other countries. For instance, in 2012, investment opportunities to building retrofits in the entire U.S. are offered with \$279 million. The motivation for this market expansion is from the higher energy efficiency after building retrofit that helps the developers save $30 \%$ annually for electricity use. The return, which is more than $\$ 1$ trillion over 10 years, benefits them 3.58 times higher than the investment itself [31]. This high profit rate is not only a driving force for expanding the nation-wide market, but also at the smaller ones such as at city scale, due to the projects' location.

\subsubsection{Job creation}

The bigger size of Green Building markets increases labor demand which covers the employments directly associated with the implementation of Green Buildings as well as those concerning with supply chains. Among them, the direct employments cover the jobs in construction, installation, operation and maintenance process. These additional jobs can also cover a wide spectrum of professions from entry-level to highly skilled labors. Besides direct and indirect employments, investments into Green Building retrofits can also create more induced jobs which are fostered by the employees who get paid from the newly added jobs for further services or products on the markets.

According to Pollin et al., every $\$ 1$ million investment into building retrofits for higher energy efficiency potentially creates 7.0 direct jobs, 4.9 indirect jobs and 4.8 induced jobs in the U.S. The total job creation (16.7 jobs) is 2,2 times higher than those from fossil fuel related investments [40]. Employments in the construction sector are estimated to share $30.1 \%$ number of direct jobs, which is the highest in the "green" economy of the U.S. [41]. Besides that, direct jobs from real estate, rental and leasing properties account for $19.6 \%$, which is another considerate portion in this fastgrowing and relatively well-paid economy [16].

In the latest report of the Multifamily Green Bond program, 9,000 well-paid jobs associated with construction or renovation of the certified Green Building are created and supported within 2019 that added to 180,000 green jobs in cumulation during 2012-2019 [11]. On average, the annual payment for these jobs is $\$ 42,000$ [12]. 
Even though these benefits are calculated at the national scale, it can also be an evidence for job creation at smaller scale such as regions and cities because Green Building related jobs are geographically diverse across several cities based on projects' location. These numbers do not cover the potential jobs created by a higher demand from households and businesses when they have more to spend after the profits gained from utility savings. Therefore, the actual number of job creation might be higher than estimated.

\subsubsection{Higher tax collection}

At the city level, even though waved taxes and fees are applied for some green investors as an encouragement in planning tools to foster the development of Green Buildings, a higher tax contribution can be collected from the activities associated with these buildings' construction and retrofit. These taxes arise from the Green Building supply chains, a higher transaction rate in both selling and renting the properties and the newly added jobs. Besides, the transactions with higher property value and more well-paid jobs also add to the amount of income taxes collected at the end of the day.

Within the limited body of literature on this topic, a study by Shazmin et al. figured out an increase of tax of $\$ 9$ collected by the local governments of Kulai Municipal, Malaysia, for every $25 \%$ tax grant when they wave $25-75 \%$ of the tax for Green Building developers. These taxes are estimated to be contributed by the green investors using Green Roof, Green Façade and solar cells [42].

\section{Discussion}

Aiming to contribute to the emerging literature on this topic, the paper has reviewed and gathered the values of Green Buildings from different secondary materials. Besides providing a confirmation on these values at building scale, the paper also discusses further of the initial cost, which is commonly believed to be the top barrier for investment in Green Buildings. According to the findings, even though Green Buildings are recognized to cost more at the beginning; however, the costs can be optimized by an early involvement of green elements in the planning phases, by negotiation as well as by financial and non-financial incentives. These costs are also paid back shorter through time, and the benefit returns are considerable. While most of the other secondary materials focus on the metrics of values from Green Buildings, the discussion on the initial cost in this paper provide the investors further insights into the cost and benefit balance of Green Building development that might help them in their decision-making process. Moreover, the findings of the paper also indicate potential values of Green Buildings at the city scale, which have not been widely documented so far. Certain connections between the values at two scale were also discussed.

Arose from these findings and particularly from the limitations of the reviewed data, the following part of this chapter would discuss further the actual economic benefits of Green Buildings as well as the potential orientations of the upcoming research on this topic.

Firstly, even though certain values of Green Buildings at building and city level are aforementioned, there are some benefits that are hardly converted into economic values due to a lack of conversion measures and data. Despite a large range of uncertainty, these benefits are not zero and in certain cases, might be considerable. The actual values of Green Building therefore are possibly greater than the summary in this paper.

In most literature on empirical studies so far, certified buildings are often selected as case studies because their relevant data can be provided by the rating system organizations. However, there are developers who do a majority of their projects green and do not seek for certification for all of these buildings [9]. Taking these non-labeled Green Buildings into account, the actual values from Green Building could be higher than estimations at both building and city levels.

Secondly, data availability is considered as a great challenge in assessing the values of Green Building since data about building costs often are not assessed publicly. Also, in some reports, for example from the WorldGBC, even though some projects are highlighted at the successful case studies, the reliability level of these data remains unknown because they are provided by the project teams and having few observations from the third-party.

As seen from the results, data concerning this topic from North America and following by Europe is more common to find than from the other parts of the world. On one hand, these data help the stakeholders not only in these countries, 
where data are relatively available, but also in the other countries to have an overview on what have been done and what to expect from the development of Green Building. However, on another hand, as Green Buildings aim the distinct targets and cost differently in various locations and development contexts, these data cannot precisely reflect the situations globally. Therefore, developers from the other countries still need diverse factors such as natural and socioeconomic conditions to form the proper strategies and approaches and to estimate the benefits they may have from the investment to Green Buildings. For example, depending on the electricity cost rate at each country, the financial benefits in return may vary that effects the motivation for investments in energy efficiency. In the future, when Green Building development reaches further, it is expected that a more global and objective view can be carried out to review the variety of values from different countries worldwide.

Thirdly, sufficient metrics to measure the contributions of Green Buildings in property rate should be taken into account. Among them, building location can help increase 10.5\% of the transaction price of certified Green Buildings located within $1 \mathrm{~km}$ from the city centers in Finland, France and Germany [43]. Therefore, even though many studies found that Green Building has higher asset value, the increase portion obtained from land value should be excluded to have a more precise reflection of the actual value of Green Buildings.

Fourthly, on one hand, the higher property value of Green Building allows the investors to have a more effective investment. On the other hand, the increases in initial cost to purchase or rent these properties result in a critical question that whether these building would be less affordable. This question can be answered when the life cycle of a building is reviewed, which reveals comprehensively the actual values of a project in general. Particularly, Green Buildings economically benefit their users, regardless being their owners or renters, in a long run. Therefore, although paying higher for buying or leasing, the users gain collective benefits during the operation and maintenance of the buildings. Due to this saving, it does not necessarily mean that Green Buildings are affordable for only residents and firms with better financial backgrounds.

Finally, as the existing literature still have some topics remaining uninvestigated, they might be the further concerns of the upcoming research in the future, especially on the wider scale rather than building scale. For instance, the willingness to pay more for Green Building from developers expresses an increasing interest in sustainable business development in general. Therefore, thanks to the activities associated with Green Building new construction and building retrofit, all involved stakeholders can be benefited in their brandings, from the owners/developers to the investors, constructors, city government and so on. Since there have been a few data providing the precise values gained from these activities, it remains an interesting research question for data collectors and analysts to measure how far the marketing values bring to multiple stakeholders which include values at the city level.

The values of Green Building at building and city level have an obvious connection to each other that certain values at the city level are arose from the sum of values from single Green Buildings, such as a smaller pressure on different urban technical infrastructure systems thanks to the smaller use of energy and water and amount of waste discharged. At a wider scale, the synergy effects created by the other single values from building level can create a much better whole, for example the emerging economy sector in some markets due to the transaction of Green Buildings and the manufacture as well as the supply chain of their materials. Moreover, communities living in such areas where the green projects are built might also gain further values resulting directly from economic benefits and indirectly from other social-environmental effects. They are not often mentioned in studies due to the missing metrics to measures; however, the upcoming research may explore them as a potential topic due to their importance to sustainable development.

\section{Conclusion}

In conclusion, compared to conventional buildings, Green Buildings are likely to bring more values in various ways at both building and city level. At building level, developers are benefited from the operation and maintenance thanks to the higher efficiency in building performance, the big value returned from a small initial cost, a shorter payback period, higher property value and higher transaction, rental and occupancy rates as well as the improvement in occupant healthy and productivity. At the city level, even though social responsibility encourages investors and their governments to go green, it also shows business benefits via the saving in infrastructure investment, the market expansion, a higher job creation rate and a greater tax contribution. Certain connection of values between the two scale are also included and 
discussed.

The summarized data in the paper indicate the presence and variety of Green Buildings' values at both building and city scales. However, as these values are calculated from the measurable benefits such as those relating to utility an from the certified Green Buildings, the actual values could be higher due to the missing metrics to estimate the economic outcomes from the other benefits as well as from the Green Building features in non-certified buildings. The data availability is also a great challenge to take a comprehensive overview on Green Buildings' values. Due to these missing data and literature, it remains potential research questions for the following studies on this topic. In the future, with more data on a broader concern and at more locations, it would offer greater possibilities to figure out to which extent a Green Building would bring values to the benefit-holders depending on certain situations.

Last but not least, the findings of this paper once again prove the positive relations between environmental and economic benefits at both building and city scale. Therefore, these findings hopefully can be used to promote the development of Green Building at multiple scales from building to different urban scales and possibly to bigger scales such as national- and world-wide.

\section{References}

[1] International Energy Agency and United Nations Environment Programme. 2018 Global Status Report: Towards a Zero-Emission, Efficient and Resilient Buildings and Construction Sector. Global Alliance for Buildings and Construction. 2018.

[2] WorldGBC. The benefits of Green Buildings. World Green Building Council. Available from: https://www. worldgbc.org/ [Accessed 22nd June 2020].

[3] Kats G, Alevantis L, Berman A, Mills E, and Perlman J. The Costs and Financial Benefits of Green Buildings. A report to California's sustainable building task force. Sustainable Building Task Force, U.S. 2003. Available from: http://www.usgbc.org/sites/default/files/costsofgreen_0.pdf.

[4] Fontão E. The reality of spatial plans is delaying the growth of sustainable buildings. Energy Reports. 2020; 6: 3843. Available from: doi: 10.1016/j.egyr.2019.08.015.

[5] Haruna A, Shafiq N, Montasir OA. Building information modelling application for developing sustainable building (Multi criteria decision making approach). Ain Shams Engineering Journal. 2020. Available from: https://doi. org/10.1016/j.asej.2020.06.006.

[6] Grover R, Emmitt S, Copping A. Critical learning for sustainable architecture: Opportunities for design studio pedagogy. Sustainable Cities and Society. 2020; 53: 101876. Available from: https://doi.org/10.1016/ j.scs.2019.101876.

[7] Attia AS. Traditional multi-story house (Tower House) in Sana'a City, Yemen. An example of sustainable architecture. Alexandria Engineering Journal. 2020; 59(1): 381-387. Available from: doi: 10.1016/j.aej.2020.01.001.

[8] McGraw-Hill Construction. SmartMarket Report: World Green Building Trends. Design and Construction Intelligence, U.S. 2013.

[9] Dogde Data \& Analytics. SmartMarket Report: World Green Building Trends 2018. Design and Construction Intelligence, U.S. 2018. Available from: https://www.worldgbc.org/sites/default/files/World\%20Green\%20 Building\%20Trends\%202018\%20SMR\%20FINAL\%2010-11.pdf.

[10] Conlon E, Glavas A. The relationship between proactive corporate sustainability and firm financial performance. Proceedings of the Annual Meeting of the Academy of Management. U.S.; 2012. p. 3-7.

[11] Fannie Mae. A Decade of Positive Impact. Multifamily Green Bond Impact Report 2019. Fannie Mae, U.S. 2020. Available from: https://multifamily.fanniemae.com/media/8921/display.

[12] Fannie Mae. Multifamily Green Bond Impact Report 2012-2018. Fannie Mae, U.S. 2019. Available from: https:// multifamily.fanniemae.com/media/13511/display.

[13] Eichholtz P, Kok N, Quigley JM. Doing well by doing good? green office buildings. American Economic Review. 2010; 100(5): 2492-2509. Available from: doi: 10.1257/aer.100.5.2492.

[14] Laski J. Doing right by planet and people: The business case for health and wellbeing in Green Building. World Green Building Council. 2018.

[15] Fan K, Chan EHW, Chau CK. Costs and benefits of implementing Green Building economic incentives: Case study of a gross floor area concession scheme in Hong Kong. Sustainability. 2018; 10(8): 2814. Available from: doi: $10.3390 /$ su10082814. 
[16] USGBC. The business case for Green Building. U.S. Green Building Council. 2015. Available from: https://www. usgbc.org/articles/business-case-green-building [Accessed 16th July 2020].

[17] Olubunmi OA, Xia PB, Skitmore M. Green building incentives: A review. Renewable and Sustainable Energy Reviews. 2016; 59: 1611-1621. Available from: doi: 10.1016/j.rser.2016.01.028.

[18] Dwaikat LN, Ali KN. Green Buildings cost premium: A review of empirical evidence. Energy and Buildings. 2016; 110: 396-403. Available from: doi: 10.1016/j.enbuild.2015.11.021.

[19] Dogde Data \& Analytics. SmartMarket Report: World Green Building Trends 2016. Design and Construction Intelligence, U.S. 2016.

[20] Ott C, Hahn J. Green pay off in commercial real estate in Germany: Assessing the role of Super Trophy status. Journal of Property Investment \& Finance. 2018; 36(1): 104-124. Available from: doi: 10.1108/JPIF-03-20170019.

[21] Mangialardo A, Micelli E, Saccani F. Does sustainability affect real estate market values? empirical evidence from the office buildings market in Milan (Italy). Sustainability. 2018; 11(1): 12. Available from: doi: 10.3390/ su11010012.

[22] Fesselmeyer E. The value of green certification in the Singapore housing market. Economics Letters. 2018; 163: 36-39. Available from: doi: 10.1016/j.econlet.2017.11.033.

[23] Harris F. Why green real estate is the way forward. JLL. 2018. Available from: https://www.jll.pe/en/trends-andinsights/workplace/why-green-real-estate-is-the-way-forward [Accessed 9th July 2020].

[24] Hui ECM, Tse C, Yu K. The effect of beam plus certification on property price in Hong Kong. International Journal of Strategic Property Management. 2017; 21(4): 384-400. Available from: doi: 10.3846/1648715X.2017.1409290.

[25] Zhang L, Liu H, Wu J. The price premium for green-labelled housing: Evidence from China. Urban Studies. 2017; 54(15): 3524-3541. Available from: doi: 10.1177/0042098016668288.

[26] Devine A, Kok N. Green certification and building performance: Implications for tangibles and intangibles. The Journal of Portfolio Management. 2015; 41(6): 151-163. Available from: doi: 10.3905/jpm.2015.41.6.151.

[27] Stanley J, Wang Y. An analysis of LEED certification and rent effects in existing U.S. office buildings. In Energy Efficiency and the Future of Real Estate. N. E. Coulson, Y. Wang, and C. A. Lipscomb, Eds. New York: Palgrave Macmillan US; 2017. p. 101-137.

[28] Newell G, MacFarlane J, Walker R. Assessing energy rating premiums in the performance of green office buildings in Australia. Journal of Property Investment \& Finance. 2014; 32(4): 352-370. Available from: doi: 10.1108/JPIF10-2013-0061.

[29] Miller N, Spivey J, Florance A. Does green pay off? The Journal of Real Estate Portfolio Management. 2008; 14(4): 385-400.

[30] WorldGBC. Building the Business Case: Health, Wellbeing and Productivity in Green Offices. WorldGBC, Canada. 2016. Available from: https://lightingeurope.org/images/HCL/WGBC_Oct2016_health_wellbeing_productivity_ in_green_offices.pdf.

[31] DB Climate Change Advisors. United States Building Energy Efficiency Retrofits. Market sizig and financing models. Germany. 2012. Available from: https://www.rockefellerfoundation.org/wp-content/uploads/United-StatesBuilding-Energy-Efficiency-Retrofits.pdf.

[32] United Nations. Department of Economic and Social Affairs, and Population Division. World Urbanization Prospects: The 2018 Revision (ST/ESA/SER.A/420). United Nations, New York, (ST/ESA/SER.A/420). 2019.

[33] Bouton S, Newsome D, Woetzel J. Building the Cities of Future with Green Districts: Better Design Can Make Sense Aesthetically, Environmentally-and Economically. McKinsey \& Company. 2015.

[34] HMFH Architects, Inc. and Vermont Energy Investment Corp. The Incremental Costs and Benefits of Green Schools in Massachusetts. Massachusetts Technology Collaborative, Massachusetts. 2005.

[35] Foster J, Lowe A, Winkelman S. The Value of Green Infrastructure for Urban Climate Adaptation. The Center for Clean Air Policy, Washington, DC. 2011.

[36] City of Toronto. City of Toronto green roof bylaw. City of Toronto. Available from: https:/www.toronto.ca/citygovernment/planning-development/official-plan-guidelines/green-roofs/green-roof-bylaw/ [Accessed 28th August 2020].

[37] Clark C, Adriaens P, Talbot FB. Green roof valuation: A probabilistic economic analysis of environmental benefits. Environmental Science \& Technology. 2008; 42(6): 2155-2161. Available from: doi: 10.1021/es0706652.

[38] City of Chicago. Chicago green roofs. City of Chicago. Available from: https://www.chicago.gov/content/city/en/ depts/dcd/supp_info/chicago_green_roofs.html [Accessed 28th August 2020].

[39] Holbrook E. Even with Covid-19, Green Buildings materials market expected to grow by $\$ 187$ Billion. 
Environment + Energy Leader. Available from: https://www.environmentalleader.com/2020/06/even-with-covid19-green-buildings-materials-market-expected-to-grow-by-187-billion/ [Accessed July 12nd 2020].

[40] Pollin R, Heintz J, Garrett-Peltier H. The Economic Benefits of Investing in Clean Energy. How the Economic Stimulus Program and New Legislation can Boost U.S. Economic Growth and Employment. University of Massachusetts, U.S. 2009. Available from: http:/www.peri.umass.edu/fileadmin/pdf/other_publication_types/ green_economics/economic_benefits/economic_benefits.PDF.

[41] Bowen A, Kuralbayeva K, Tipoe EL. Characterising green employment: The impacts of 'greening' on workforce composition. Energy Economics. 2018; 72: 263-275. Available from: doi: 10.1016/j.eneco.2018.03.015.

[42] Shazmin SAAA, Sipan I, Sapri M, Ali HM, and Raji F. Property tax assessment incentive for green building: Energy saving based-model. Energy. 2017; 122: 329-339. Available from: doi: 10.1016/j.energy.2016.12.078.

[43] Porumb VA, Maier G, Anghel I. The impact of building location on green certification price premiums: Evidence from three European countries. Journal of Cleaner Production. 2020; 272: 122080. Available from: doi: 10.1016/ j.jclepro.2020.122080. 